NASZA DERMATOLOGIA Online OUR DERMATOLOGY Online

Source of Support: Nil

Competing Interests: None declared

\section{EPONYMS IN DERMATOLOGY LITERATURE LINKED TO NORWAY}

\author{
Khalid Al Aboud ${ }^{1}$, Daifullah Al Aboud ${ }^{2}$ \\ ${ }^{1}$ Pathology Department, Wake Forest University, Winston-Salem, NC, USA \\ ${ }^{2}$ Dermatology Department, Taif University, Taif, Saudi Arabia
}

Corresponding author: Dr. Khalid Al Aboud

amoa65@hotmail.com
An eponym is a word derived from the name of a person. The use of eponyms has long been contentious, but many remain in common use.

Medical literature in general, has many eponyms, coined after scientists from all over the world.

In this communication, we shall highlight on selected eponyms linked to Norway in dermatology literature.

Norway has a population of about 5 million and it is the second least densely populated country in Europe. Yet, it was, and still the birthplace for great scientists. The strive for scientific advance and humanitarianism are among the characteristics of this small country. It has few examples of medical scientists that has discovered and cultivated unknown territory [1].

Most dermatologists are aware of the term „Norwegian scabies", which is currently best known as „crusted scabies”, a condition where the patient may harbor up to many millions of mites. This type of scabies was called Norwegian scabies on account of its first recognition in Norway in 1848 among patients with leprosy [2].

The well-known whonamedit website, (www.whonamedit. com), listed till now more than 30 medical eponyms linked to Norway.

But some of these medical eponyms are no longer in common use in medicine.

For example, Følling's disease or Følling's syndrome is the eponymous name for the autosomal recessive metabolic genetic disorder; Phenylketonuria (PKU) [1] .

Asbjørn Følling (1888-1973), was a Norwegian physiologist. He discovered ,his disease" (phenylketonuria = PKU) in 1934. He discovered the first link between metabolic disease and brain development [1].

Another example of medical eponym linked to Norway, which is not popular at present time is Harbitz-Müller syndrome, which is best known, as familial hypercholesterolemia [3]. Francis Gottfred Harbitz (1867-1950), and Carl Arnoldus
Müller (1886-1983), were both Norwegian physicians. From 1925 to 1938, the pathologist, Francis Harbitz, published several reports on sudden death and xanthomatosis. Harbitz called attention to certain peculiarities of the xanthomatosis. Microscopically he found that the so-called foam cells are more marked and more characteristic than in senile arteriosclerosis [3].

However, some medical eponyms linked to Norway are still in common use.

In Table I [4-10], we listed selected eponyms in dermatology literature, which are linked to Norway.

\section{REFERENCES}

1. Lie SO: [Folling's disease]. Tidsskr Nor Laegeforen. 2000;120:3042-3.

2. McCarthy JS, Kemp DJ, Walton SF, Currie BJ: Scabies: more than just an irritation. Postgrad Med J. 2004;80:382-7.

3. Ose L: [Müller-Harbitz disease--familial hypercholesterolemia]. Tidsskr Nor Laegeforen. 2002;10;122:924-5.

4. Hem E: Boeck's sarcoidosis-a centennial. Int J Dermatol. 2000;39:545-9.

5. Epstein WL: „Multiple benign sarkoid of the skin” by Boeck, December 1899. Commentary: What begot Boeck? Arch dermatol. 1982;118:711-22.

6. Hansen W, Freney J: [Armauer Hansen (1841-1912), portrait of a Nordic pioneer]. Hist Sci Med. 2002;36:75-81.

7. Cohen MM, Vidaver D: The man behind the syndrome: Sigvald Refsum. J Hist Neurosci. 1992;1:277-84.

8. Stokke O: [Refsum disease--rare, but world-famous] Tidsskr Nor Laegeforen. 2001;121:334-5.

9. Refsum S: Heredopathia atactica polyneuritiformis (phytanicacid storage disease, Refsum's disease): a biochemically welldefined disease with a specific dietary treatment. Arch. Neurol. 1981;38:605-6

10. Ramsay BC, Meeran K, Woodrow D, Judge M, Cream JJ, Clifford Rose F, et al: Cutaneous aspects of Refsum's disease. J R Soc Med. 1991;84:559-60. 


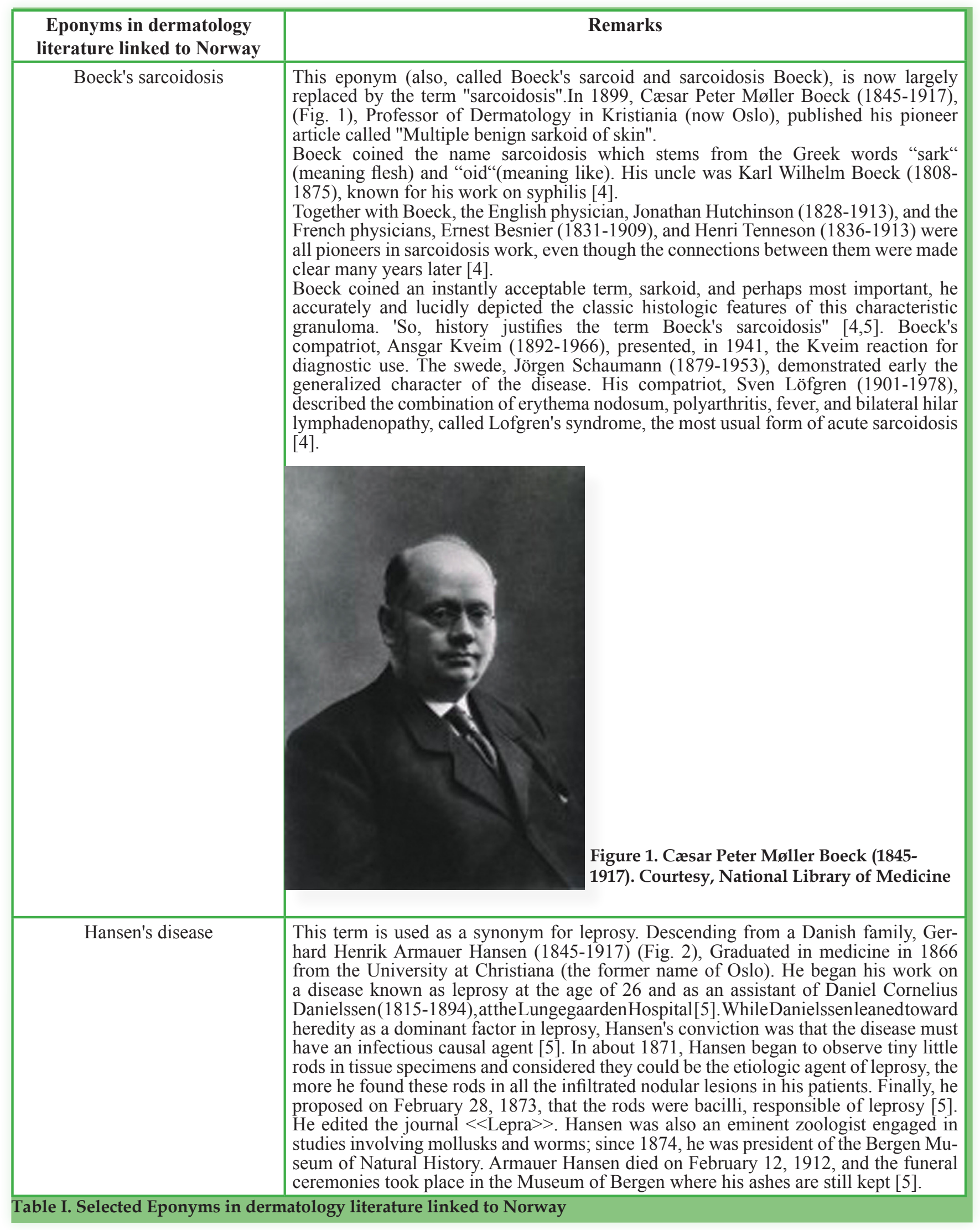




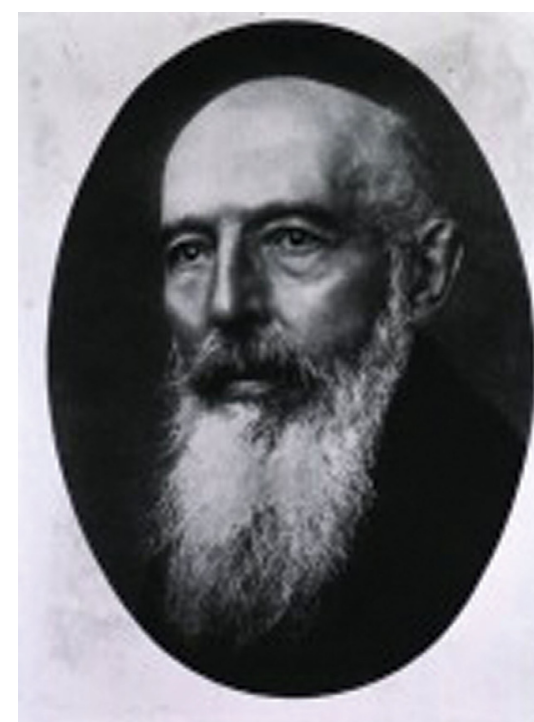

Figure 2. Gerhard Henrik Armauer Hansen (1841-1912). Courtesy, National Library of Medicine

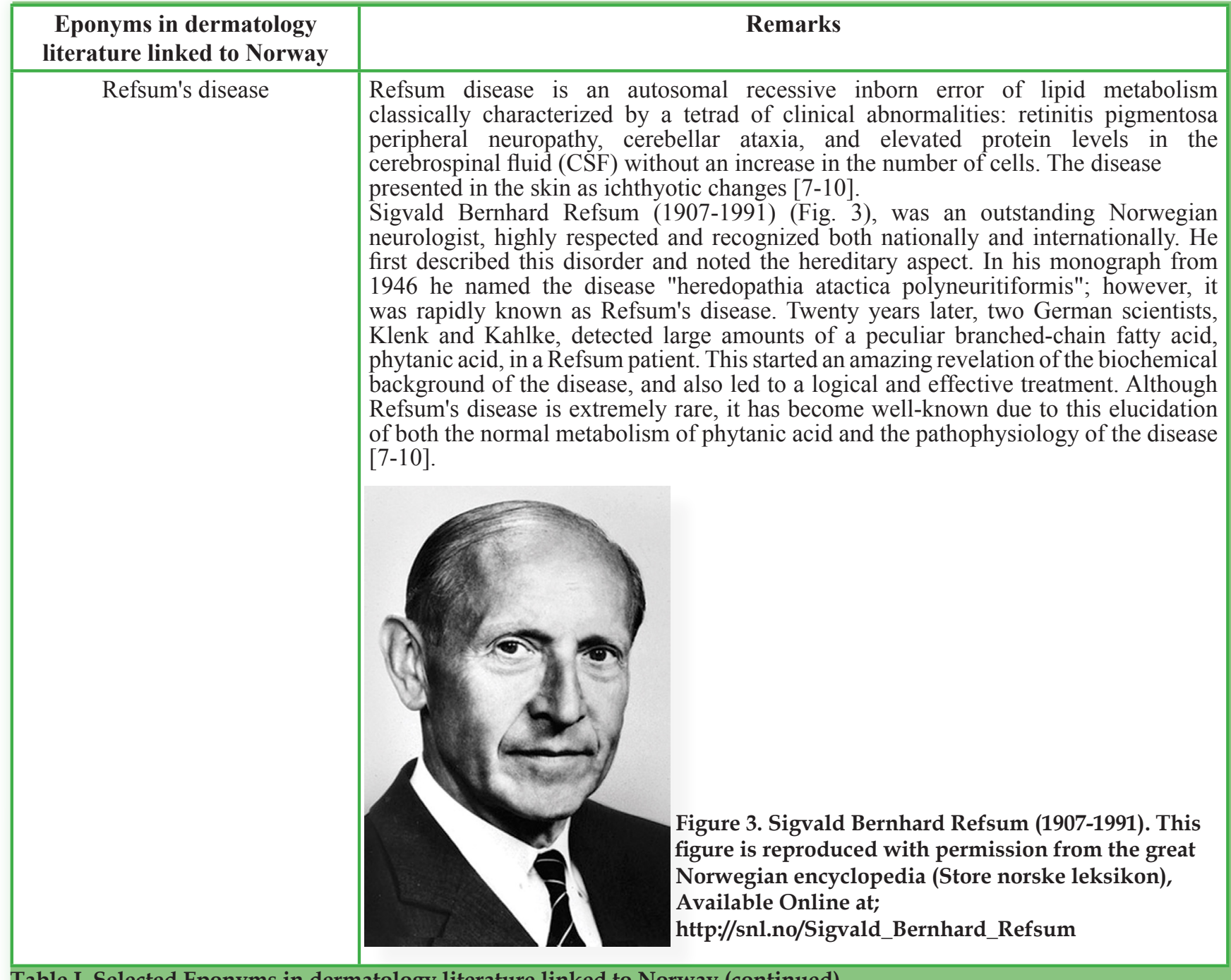

Table I. Selected Eponyms in dermatology literature linked to Norway (continued)

Copyright by Khalid Al Aboud, et al. This is an open access article distributed under the terms of the Creative Commons Attribution License, which permits unrestricted use, distribution, and reproduction in any medium, provided the original author and source are credited. 